\title{
Cymothoa recifea sp. nov. (Isopoda, Cymothoidae) from the mouths of marine fishes of Pernambuco State, Brazil ${ }^{1}$
}

\author{
Vernon E. Thatcher ${ }^{2} \&$ Francinete T. Fonseca ${ }^{3}$ \\ ${ }^{1}$ Contribution number 1565 of the Departamento de Zoologia, Universidade Federal do Paraná. \\ ${ }^{2}$ Departamento de Zoologia, Universidade Federal do Paraná. Caixa Postal 19020, 81531-980 Curitiba, Paraná, Brasil. \\ ${ }^{3}$ Laboratório de Peixes, Departamento de Biologia, Universidade Federal de Pernambuco. Rua Dom Manoel de Medeiros, \\ 52171-900 Recife, Pernambuco, Brasil.
}

\begin{abstract}
Cymothoa recifea sp. nov. (Isopoda, Cymothoidae) is described from the mouths of Centropomus undecimalis (Bloch, 1792) and Oligoplites palometa (Cuvier, 1832). The fish hosts were caught near Itamaracá and Cabo de Santo Agostinho, State of Pernambuco, Brazil. The new species bears a superficial resemblance to Cymothoa oestrum (Linnaeus, 1793) from which it differs in a number of important respects. In the new species, the basal carinae are large on pereopods 4-7 and usually pointed, whereas in C. oestrum the carinae are small on pereopods 4-6, large on 7 and not pointed. In the new species, only pleopod 1 is simple and 2-5 are provided with pockets and folds. In the other species, pleopods $1-4$ are simple and only 5 has folds.
\end{abstract}

KEY WORDS. Atlantic Ocean, isopod parasite, parasitic crustacean.

\begin{abstract}
RESUMO. Cymothoa recifea sp. nov. (Isopoda, Cymothoidae) das bocas de peixes marinhos do Estado de Pernambuco, Brasil. Cymothoa recifea sp. nov. (Isopoda, Cymothoidae) é descrito das bocas de Centropomus undecimalis (Bloch,1792) e Oligoplites palometa (Cuvier, 1832). Os peixes foram capturados perto de Itamaracá, Estado de Pernambuco, Brasil. A nova espécie apresenta uma semelhança superficial à Cymothoa oestrum (Linnaeus, 1793) da qual distinguese pôr várias características. Na nova espécie, as expansões nas bases dos pereópodos ("carinae") são grandes nos 4-7 e, geralmente, terminam em pontas agudas. Em contraste, em C. oestrum, estas estruturas são pequenas nos pereópodos 4-6, grande somente no sétimo e não têm pontas agudas. Na nova espécie, somente o pleópodo 1 é simples e 2-5 apresentam bolsas e dobras. Na outra espécie, os pleópodos 1-4 são simples e somente 5 tem dobras. PALAVRAS CHAVES. Oceano Atlântico, isópodo parasito, Crustáceo parasito.
\end{abstract}

According to TriLles (1991), 32 nominal species of Cymothoa Fabricius, 1793, occur in marine fishes world-wide with 5 of these found in Brazilian waters. THATCHER (2000) reported only 4 species of this genus from South America, but THAтснек et al. (2003) described a new species and compared it with 6 other species that have been attributed to Brazil. Thus, 7 species of Cymothoa may inhabit Brazilian coastal fishes, namely: C. brasiliensis Schiödte \& Meinert, 1884; C. catarinensis Thatcher, Loyola e Silva, Jost \& Souza-Conceição, 2003; C. excisa Perty, 1830; C. gerris Schiödte \& Meinert, 1884; C. ianuarii Schiödte \& Meinert, 1884; C. liannae Sartor \& Pires, 1998 and C. oestrum (Linnaeus, 1758). The present paper describes an additional species of this genus from marine fishes of Brazil.

\section{MATERIAL AND METHODS}

Marine fishes were netted along the coast of Pernambuco State, Brazil. The isopod parasites were removed from the mouths of their hosts and preserved in $70 \%$ alcohol. In the laboratory dissections of mouthparts, pereopods, pleopods and uropods were made using needles and a mini-scalpel. These small parts were cleared and studied in temporary preparations in pure phenol. Photographs were taken with a digital camera at five megapixels and drawings were made using these images as a basis. Measurements are in micrometers $(\mu \mathrm{m})$ unless designated as millimeters $(\mathrm{mm})$.

\section{Cymothoa recifea sp. nov. \\ Figs $1-42$}

Species description (based on 6 males and 5 females). Male (Figs 1-2): body elongate, widest at level of pereonite 4, measures 11-32 (20) mm long and 5-15 (10) mm wide. Cephalon immersed in pereonite 1 ; frons doubled downward between bases of antennae; eyes absent. Antennule (Fig. 3) stout, of 9 articles; antenna (Fig. 4) slender and shorter, also composed of 9 articles. Mouthparts (Figs 5-8): mandible with acute incisor and rounded molar process; palp slender of 3 articles, extends 


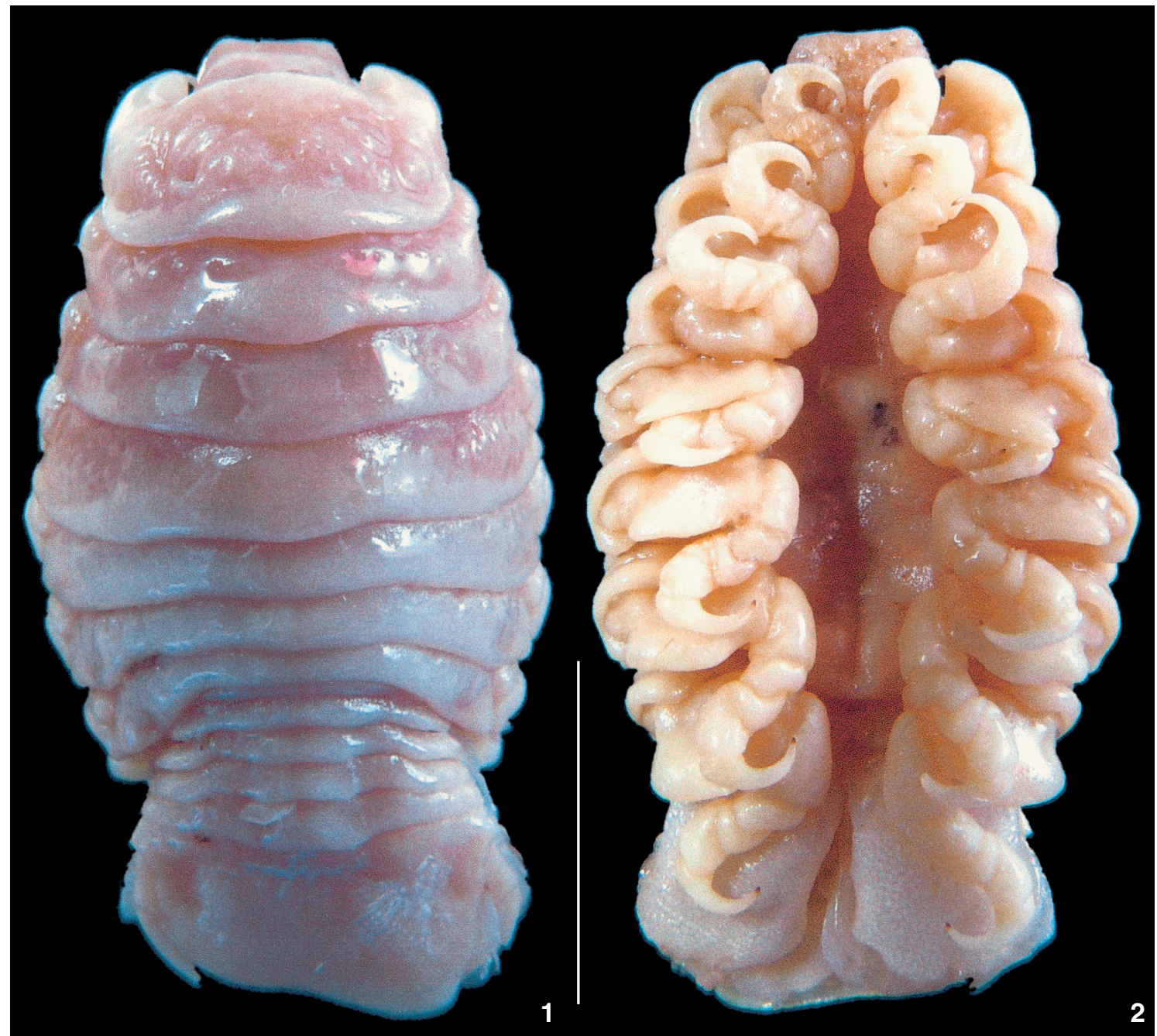

Figures 1-2. Cymothoa recifea sp. nov. male: (1) entire, dorsal; (2) entire, ventral. Scale bar = $10 \mathrm{~mm}$.

beyond mandible; maxillule with 4 subequal spines distally; maxilla bilobed, with few small spines on each lobe; maxilliped slender, palp with 4 spines distally, 3 being terminal and 1 being subterminal. Pereon: pereonite 1 longest; $2-4$ subequal in length; 5-6 subequal and about half as long as 4; pereonite 7 very short, about half as long as 6 . Antero-lateral margins of pereonite 1 rounded. Pleon not immersed in pereonite 7 , gradually expands in width from pleonite 1-5. Pereopods (Figs 1016) 1-3 small, slender, with low carinae; $4-7$ increasing in size and with high pointed carinae. Pleopods (Figs 17-21): all bilaminate; 1 simple; $2-4$ with pockets; 5 with several vertical folds; 2 with elongate, slender appendix masculinum. Uropod (Fig. 9) with elongate rami; endopod shorter than exopod. Pleotelson 2-3 times wider than long, measures 2-7 (4) $\mathrm{mm}$ long and 4-11 (7) $\mathrm{mm}$ wide.

Female (Figs 39-42). Body large, robust, 27-35 (35) mm long and 15-20 (18) mm wide; widest at level of pereonite 4. Cephalon as in male; frons bent down between bases of antennae (Fig. 42). Pereon and pleon similar to those of male. Antennae similar to those of male (Figs 28-29) but of 8 articles. Mouthparts (Figs 22-25): incisor of mandible less acute; palp shorter; maxillule as in male; maxilla bilobed with 4 spinules on one lobe and 3 on the other; maxilliped more expanded than that of male, palp with several terminal spines. Pereopods (Figs 34-38): 1-3 smaller than 4-7; carinae on 4-7 large and variable in shape. Pleopods similar to those of male but 2 lacks appendix masculinum; 1 simple; $2-4$ with pockets and 5 with verticle folds (Figs 26-27). Pleotelson wider than long. Uropods variable (Figs 30-33).

Buccal parasites of marine fishes.

Hosts. Centropomus undecimalis (Bloch, 1792) Centropomidae. Oligoplites palometa (Cuvier, 1832): Carangidae.

Revista Brasileira de Zoologia 22 (3): 517-521, setembro 2005 


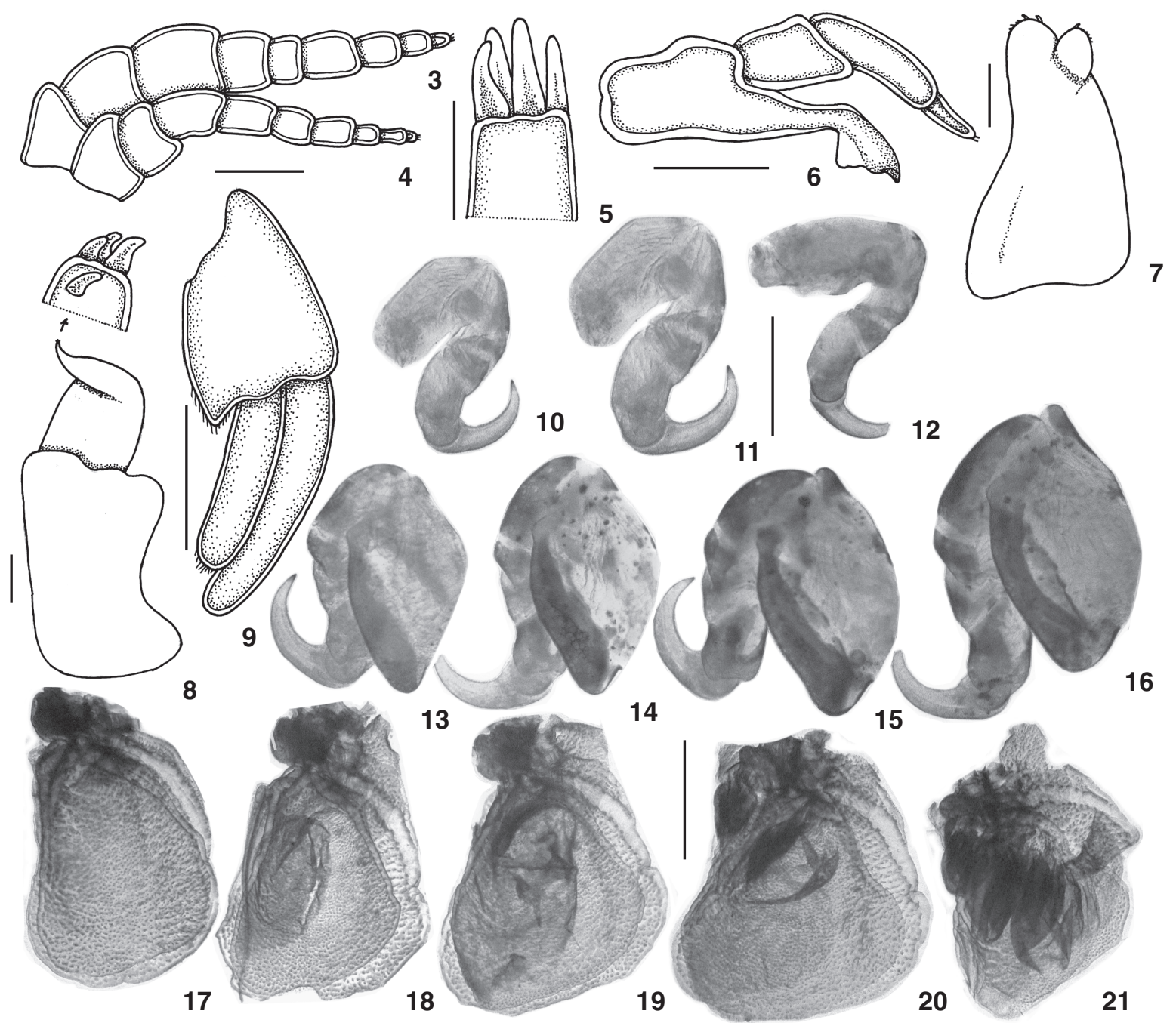

Figures 3-21. Cymothoa recifea sp. nov. male: (3) antennule; (4) antenna; (5) maxillule; (6) mandible and palp; (7) maxilla; (8) maxilliped; (9) uropod; (10-16)pereopods 1-7; (17-21) pleopoda 1-5. Scale bars: 3, 4 and $6=500,5=100,7$ and $8=200,9=1 \mathrm{~mm}, 10-21=2 \mathrm{~mm}$.

Site. Mouth, over tongue.

Localities. Canal de Santa Cruz, Itamaracá, Pernambuco State, Brazil, and Baia de Suape Cabo de Santo Agostinho, Pernambuco State, Brazil.

Type material. Holotype male, 3 paratype males and 3 paratype. Females deposited in the Crustacean Collection of the Instituto Nacional de Pesquisas da Amazônia (INPA), Manaus, Amazonas, Brazil.

Etymology. The specific name is in reference to the city of Recife, the capital of the state of Pernambuco.

\section{DISCUSSION}

Cymothoa recifea sp. nov. resembles C. oestrum in size and general form (see Tнатснек et al. 2003) but differs from the lat- ter in a number of respects. Most importantly, the pleopods of the two species are quite different. In the new species only pleopod 1 is simple while $2-4$ have pocket like structures and 5 has three or four vertical folds. This contrasts with $C$. oestrum in which pleopods 1-4 are all simple and only 5 has vertical folds. Another striking difference between these species is to be seen in the basal carinae of the pereopods. In the new species, these are large on pereopods 4-7 and usually pointed. In C. oestrum, these structures are small on pereopods 4-6, large on 7 and usually not pointed. Other differences can be found in the relative length of the pereonites; 5-7 are very short on the midline of the new species while in C. oestrum only 7 is short. Also, the maxilla of the new species has a distinct form and more spines than that of the other species.

Revista Brasileira de Zoologia 22 (3): 517-521, setembro 2005 

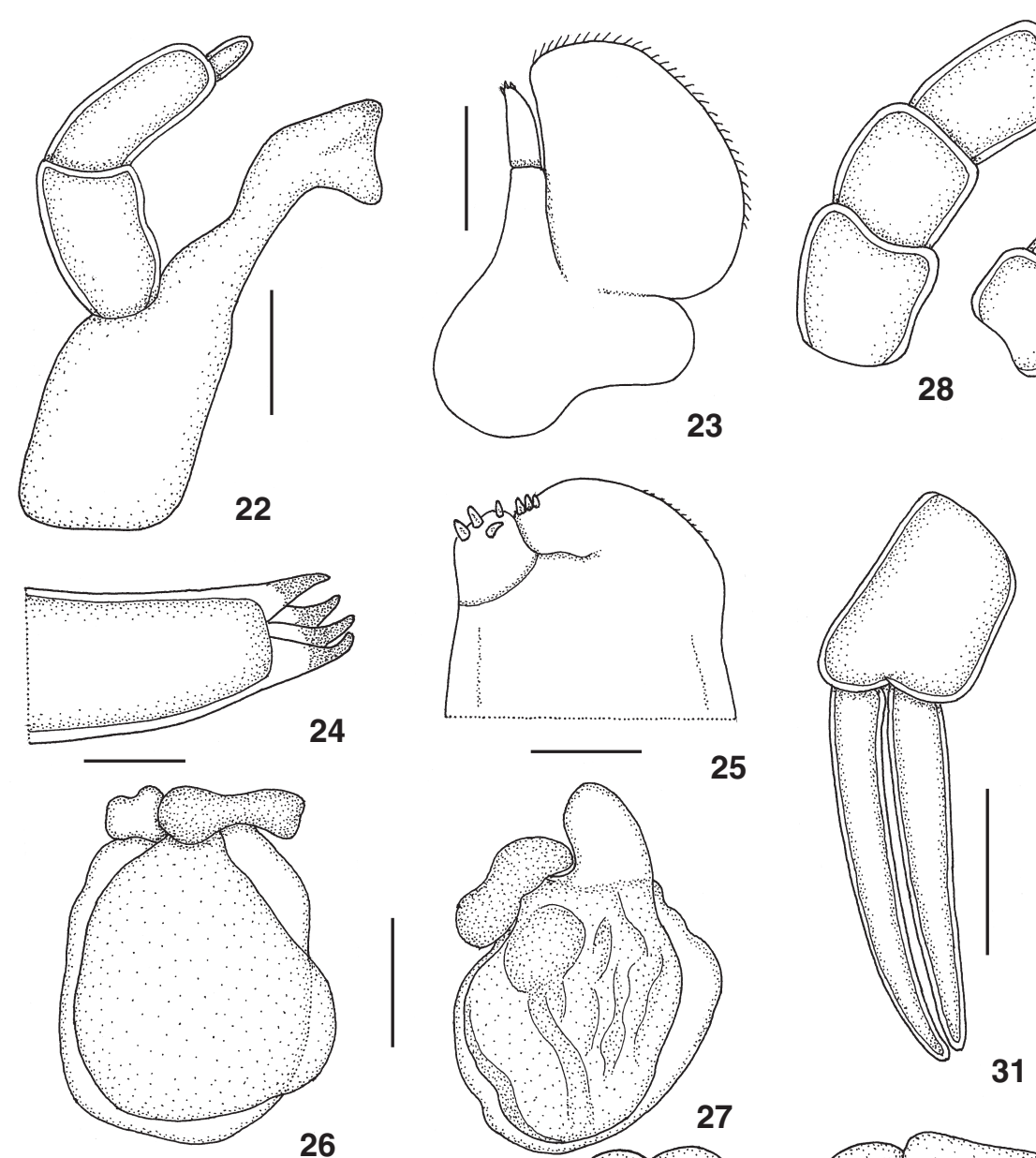

24

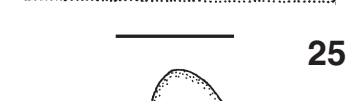

26

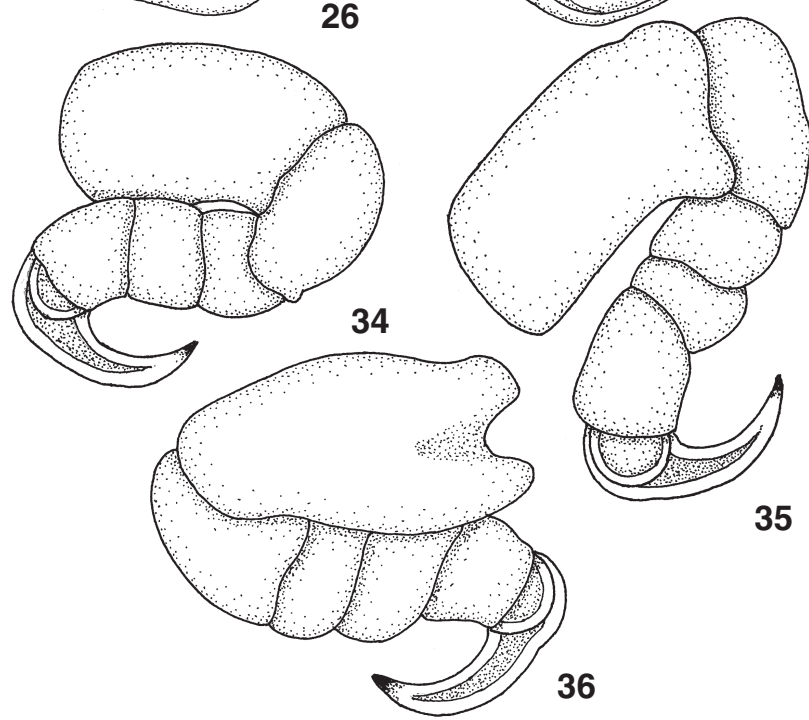

27

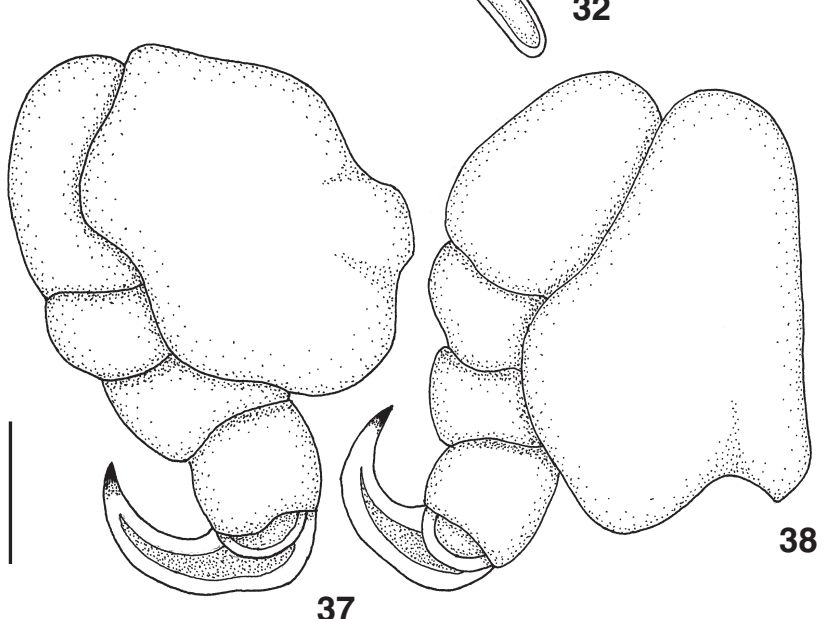

33

37

Figures 22-38. Cymothoa recifea sp. nov. female: (22) mandible and palp; (23) maxilliped; (24) maxillule; (25) maxilla; (26) pleopod 1; (27) pleopod 5; (28) antennule; (29) antenna; (30-33) uropods; (34-38) pereopods: (34) pereopod 1; (35) pereopod 3; (36) pereopod 4; (37) pereopod 5; (38) pereopod 7. Scale bars: $22=500,23=1 \mathrm{~mm}, 24=100 ; 25=200 ; 26-27=3 \mathrm{~mm}, 28-29=500,30=1 \mathrm{~mm}$, $31-32=2 \mathrm{~mm}, 33=1 \mathrm{~mm}, 34-38=2 \mathrm{~mm}$.

Revista Brasileira de Zoologia 22 (3): 517-521, setembro 2005 


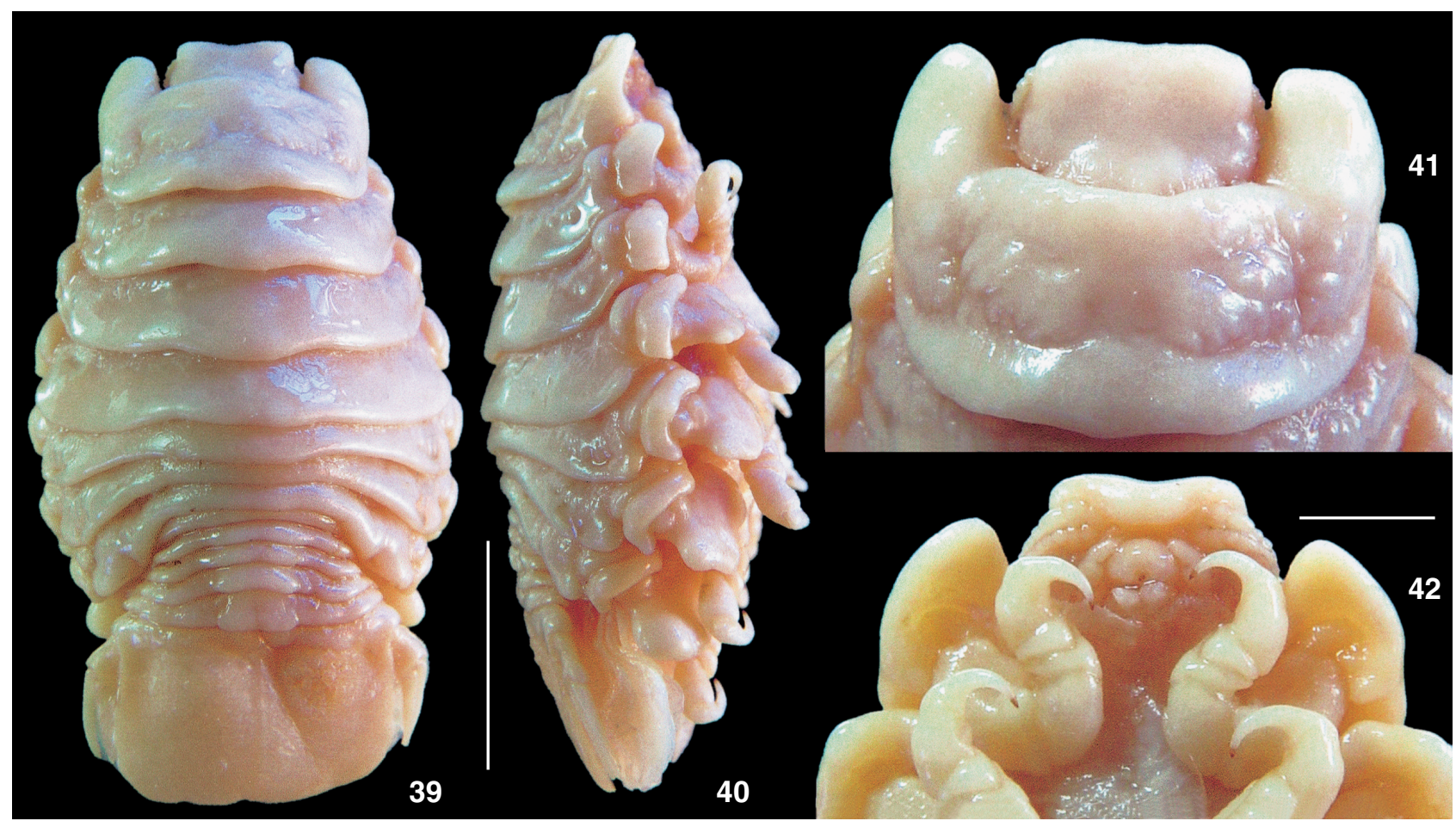

Figures 39-42. Cymothoa recifea sp. nov. female: (39) entire, dorsal; (40) entire, lateral; (41-42) anterior extremity: (41) dorsal; (42) ventral. Scale bar : 39 and $40=10 \mathrm{~mm}, 41$ and $42=3 \mathrm{~mm}$.

\section{REFERENCES}

Thatcher, V.E. 2000. The isopod parasites of South American Fishes, p. 193-226. In: G. Salgado-Maldonado; A.N. GarciaAldrete \& V.M. Vidal-Martinez. Metazoan Parasites in the Neotropics. México, Universidad Nacional Autónoma de México Press, 310p.

Thatcher, V.E.; J. de Loyola e Silva; G.F. Jost \& J.M. Souza-ConceiÇão. 2003. Comparative morphology of Cymothoa spp.
(Isopoda, Cymothoidae) from Brazilian fishes, with the description of Cymothoa catarinensis sp. nov. and redescriptions of C. excisa Perty and C. oestrum Linnaeus). Revista Brasileira de Zoologia, Curitiba, 20 (3): 541-552.

Trilles, J.P. 1991. Catalogue mondial des Cymothoidae. Studia Marina, Kotor, 21/22 (1-2): 5-288.

Received in 05.VIII.2004; accepted in 17.V.2005. 